The first issue of The Forestry Chronicle appeared in mimeographed form in July 1925.

The second one appeared in December of that year to complete what was to be Volume 1. (Numbering started with the second issue of the following year.) Now, in 1974, we see the arrival of Volume 50 , complete with an audio supplement - very different in appearance from that first venture. Here, K. G. Fensom, Editor from 1945 to 1951 , and now CIF Historian, looks at the origins of the Chronicle in

\section{Reminiscences of an Editor}

The birth of The Forestry Chronicle, like the birth of the blues, was largely one man's inspiration. That man was Arthur Herbert Richardson, then and throughout his long and disinguished career a reforestation specialist in the Ontario Forestry Branch in Toronto. At college he had published the McMaster University Monthly for two years when an Arts student, had there acquired a taste for composition, and a fondness for the printed word that would tell it like it is. He suggested to Dr. C. D. Howe, current president of the Canadian Society of Forest Engineers, that a quarterly technical journal be published, and that it be named The Forestry Chronicle. Dr. Howe agreed but said that no supporting finances would be available. As Richardson said he could do without initial financing Dr. Howe gave his personal support and blessing. That was all the encouragement Richardson needed.

He immediately assembled material, and put papers through a hand operated mimeograph machine, a prized possession of the Ontario Forestry Branch. That was in July 1925 and from then up to the end of 1928 he churned out, at irregular intervals, issues of what might be described as the gestation of The Forestry Chronicle to be - articles, comments, reports, personalia. During this period - "the paper, labour for mimeographing mailing envelopes and postage were all supplied gratuitously by His Majesty's Government." And so, without either Richardson or the Ontario Forestry Branch it is possible that The Forestry Chronicle might never have been conceived.

This fledgling publication, placed on an annual budget in 1927, would blossom into a printed quarterly in 1929 with a format that would remain unchanged up to and including December 1967. Said Richardson in his first report to members for the year ending December 31, 1925 - "I found that I was expected to issue from time to time, a news letter of a few pages containing items of a personal nature as well as Society affairs. Also, it had been customary to send out from time to time articles of members which fell in a class between being popular enough for 'Forest and Outdoors' and not of sufficient interest for the 'Journal' (of Forestry). Instead of sending these out as they came along I decided to save them up for two or three months, place them in an inexpensive binder, and mail them out in booklet form. When this was done the material contained could hardly be called a news letter, so the name 'Forestry Chronicle' was given." Other names considered Forestry in Canada, Canadian Forestry, Acta Forestalia, Canadian Forestry Quarterly.

Richardson tried publishing annual meeting papers in advance of their presentation. He thought that members would thus be better equipped to participate in freewheeling discussion at ensuing meetings. But it did not work out that way, and the practice was abandoned. Subsequently further similar attempts would be made by other regimes, but no established routine was developed, probably because authors felt that, by exposure prior to a meeting, their papers might be downgraded in respect to freshness and interest.

Although only a few articles during the terms of his editorship from 1925-1934 and from 1937-1938 were unsolicited, he rejected suggestions that foresters had nothing to say nor ability to say it. "Those who can must write", he declared.

In 1931 he deplored the scarcity of articles received from members. Even his big 82-page issue of June 1931 was put together only by frantic searching for copy. It would be a recurring and frequently stated problem throughout the years. Also, this was the issue in which, in addition to a galaxy of articles on many phases of forestry, controversial correspondence was published for the first time. This was a small beginning of many such features to come.

Because of these difficulties he often had to resort to publication of reprints. And such reprints, no matter what their quality, detract from overall originality. It was a necessary expedient and Richardson, a dedicated enthusiast, knew what he had to do and did it. His was a magnificent job of coping with many unforeseen Society problems. His frank editorials, his inborn need to stress the necessity of planned reforestation, his solicitation of advertising support and his strong views 
about obligations of professionals to be professional have earned him a permanent niche among outstanding Canadian foresters. Neither extrovert nor introvert he enjoyed espousing forestry causes and is remembered for both his good humour and his technical competence.

\section{5.}

Ellwood Wilson, a truly remarkable forester who will always be associated with numerous far-sighted innovative forestry programs which he initiated while Chief Forester for the Laurentide Co. Ltd., was editor in 1935 and 1936. He had a serious accident in 1936, during which period E. S. Davison provided pinch-hitting service in both of Wilson's offices of secretary-treasurer and editor.

Despite his short term as first part-time salaried officer of the CSFE, Wilson helped to re-spark an organization that had begun to drag a little - by writing hard-hitting editorials, by being severely but fairly critical, by pushing hard for forestry principles: especially in forest management and silviculture, by making important pronouncements on behalf of the Society, by lambasting the Ontario Government for firing forestry personnel during the depression, and generally by seizing countless opportunities to advance forestry causes.

His editorials were prolific, also his articles. He wrote copiously and well. He favoured short words, clarity, direct phrasing, and a wealth of exact detail. Many of his pronouncements, ideas and recommendations found their way into publications in the United States and Europe. Because of his achievements and innumerable articles he was one of the best known Canadian foresters, both in Canada and in the world.

His conception of the functions of The Forestry Chronicle were clearly stated - "It should endeavour to keep the members in touch with the forestry news of the world, with the progress of the profession as a whole, and with the work each man is doing. It should try to be a help to the student, to the man beginning work, and to the man who has arrived."

Wilson's distinguished and austere appearance concealed a warm heart. He was not an extrovert, but he was always ready to help people (particularly the young), to offer advice, and at the drop of a hat which he hardly ever wore to go to bat for forestry principles. In short, he was a crusader. There is no doubt whatever that the Society grew in stature during his short term - and as it had done during his presidency 1918-1920.

\section{3\%.}

Eric Druce, at the time public relations officer for the Dominion Forest Service in Ottawa, was appointed editor in 1939 and held that office until 1945. To the best of this writer's knowledge he is the only forestry undergraduate ever to have been editor of the University of Toronto paper The Varsity. His facility with words brought him into the limelight there, but he had a lot more going for him - such as, a fondness for people, an extraordinary gift of being able to speak to the point without stumbling or mumbling, and earnest consideration for all views and opinions that differed from his own. These qualities plus his experience as an editor at $\mathrm{U}$ of $\mathrm{T}$ undoubtedly caused his name to be screened out number one when the editorship was vacated for the second time by A. H. Richardson in 1939. Eric remained editor until 1945.

Sometimes short on editorials he compensated by providing manuscript specifications, distribution of questionnaires asking for opinions about format, by providing short abstracts of articles as a guide to selective reading, by featuring exchanges of controversial opinions, by creating a larger pool of potential contributors, and by giving top priority to publicity about preparation of a national CSFE forest policy.

His approach was to try to present news, views and miscellaneous other items in an entertaining way. In other words, to make information palatable and hence more digestible. In a sense he applied his instincts as an actor gained on the stage of the Ottawa Little Theatre in productions like "Outward Bound" to the business of publicizing the forestry profession and the Society. 
Although Druce was involved in a number of distracting non-forestry activities, he managed to discharge his editorial duties with credit to himself and to the Society. He was critical but only in an abstract kind of way. He did not indulge in personalities, and for being himself with no put on airs nor graces he was loved by many. In fact few foresters if any have had a wider circle of genuine friends.

This writer took over from Eric Druce in 1945 and served until 1951, having accepted this assignment with some trepidation. Though he had done a considerable amount of writing, none of it had included being an editor nor an arranger and paster up of copy for printing. However, he soon discovered that this kind of messing about was rather exciting, except when demands of a consulting practice in Montreal short-changed him for time.

When starting this assignment no preconceived ideas were held, but a first resolve was never to lock up an issue without an editorial. The idea was and is that familiar items, appearing regularly without fail, may tend to establish an aura of permanence. Some readers go automatically to editorials as others flip to crossword puzzles. Another resolve was to orient occasional issues entirely around one central theme. The December 1946 number, a concentrated review of forest education, was his first special.

$\mathrm{He}$ commented on the "spectacular failure (of foresters) in providing the correlated, sustained and complete story of forestry to the public". Perhaps some progress has been made by the profession since those words were written, but if so it has been barely discernible.

Another comment had reference to the need for an integrated physiological approach to the problems of silviculture, a grouping of several sciences and a pooling of knowledge. Advances have been made along these lines, but accumulation of new scientific knowledge has been so tremendous that large scale integration requiring more dollars and more personnel is still an improbable if not an impossible dream.

Questionnaires were again distributed, this time in 1948, asking members to give their views about readability, format, size, cover page, photographs, type setting, paper, proportion of scientific as compared with non-scientific articles, general news of sections, etc. It was the opinion of the Editorial Board that, generally speaking, the format should be tailored to conform to majority opinion. Perhaps this was the wrong approach. It could be that better guidelines might have resulted by submission to membership of a detailed editorial policy based on the more specific inside knowledge, projections, costs, capabilities and inclinations of the editor and Editorial Board.

This writer enjoyed his stint as editor. Of course there were frustrations and failures, but aren't there always? As membership increased more funds became available for bigger if not better issues. A gradually increasing number of contributors generated new ideas, and availability of additional funds made expanded coverage possible. It was an imperfect but satisfying operation, a time for learning as well as doing.

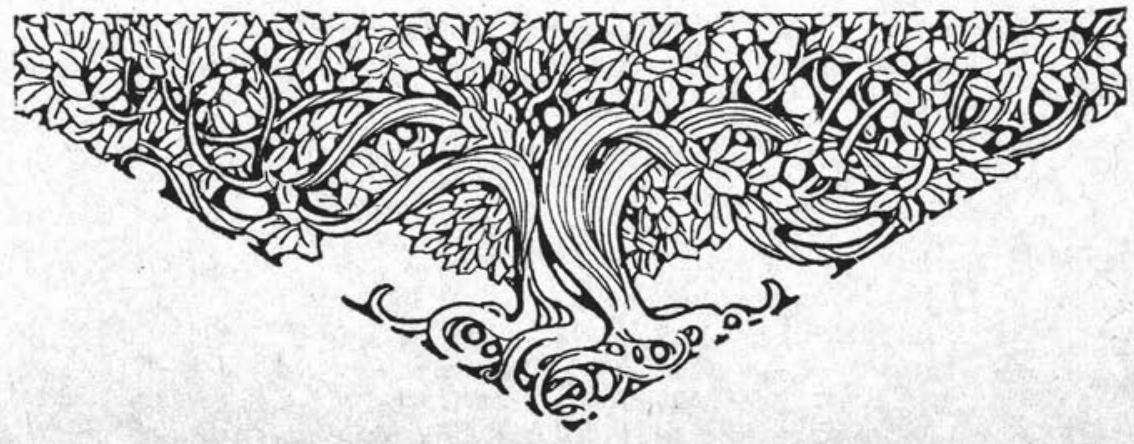

